\title{
PENGARUH PENGGUNAAN MEDIAL ARCH SUPPORT TERHADAP PENGURANGAN DERAJAT NYERI, KESEIMBANGAN STATIS DAN ACTIVITY OF DAILY LIVING PADA PENDERITA PLANTAR FACIITIS
}

\author{
Dwi Setyawan, Bhisma Murti, Hermanu Joebagio \\ Politeknik Kesehatan Surakarta Jurusan Ortotik Prostetik
}

\begin{abstract}
Plantar Facitis, Medial Arch Support, Degree Of Pain, Static Balance, Activity Of Daily Living. The case of plantar factis still a lot going on and the handling of the case there are a variety of ways including the use of tools such as the medial arch support, ultrasound therapy, medication, and surgery. The purpose of this study was to analyze the effect of the medial arch support to a reduction in the degree of pain, static balance and activity of daily living in patients with plantar faciitis. This research is kind of Randomized Control Trial (RCT) In this draft, dividing the subjects into two groups. Number of research subjects are 30 subjects were divided into two groups, one group as an experimental group treated medial arch support and one more group as a control group treated with ultrasound (US). Data collection technique used documentation study and observation. Data were analyzed using multiple linear regression analysis and statistical significance of the variables were tested by $t$ test with the results shown by the $p$ value. Significant influence use of medial arch support to the reduction of the degree of pain, static balance and activity of daily living in patients with plantar faciitis. It was demonstrated with $p<0.001$.
\end{abstract}

Keywords: Plantar Facitis, Medial Arch Support, Degree Of Pain, Static Balance, Activity Of Daily Living.

Abstrak: Plantar Facitis, Medial Arch Support, Derajat Nyeri, Keseimbangan Statis, Activity Of Daily Living. Kasus plantar factis masih banyak terjadi dan penanganan untuk kasus tersebut terdapat berbagai macam cara diantaranya penggunaan alat bantu seperti medial arch support, terapi ultrasound, obat-obatan, dan operasi. Tujuan dari penelitian ini adalah untuk menganalisis pengaruh penggunaan medial arch support terhadap pengurangan derajat nyeri, keseimbangan statis dan activity of daily living pada penderita plantar faciitis. Desain penelitian ini merupakan penelitian jenis Randomized Control Trial (RCT) Dalam rancangan ini, membagi subyek dalam dua kelompok. Jumlah subyek penelitian ini adalah 30 subyek yang dibagi menjadi dua kelompok, satu kelompok sebagai kelompok eksperimen yang diberi perlakuan medial arch support dan satu kelompok lagi sebagai kelompok kontrol yang diberi perlakuan ultrasound (US). Teknik pengumpulan data menggunakan studi dokumentasi dan observasi. Teknik analisis data menggunakan analisis regresi liner berganda dan Kemaknaan statistik dari variable diuji dengan uji t dengan hasil ditunjukkan oleh nilai $\mathrm{p}$ value. Terdapat pengaruh yang signifikan penggunaan medial arch support terhadap pengurangan derajat nyeri, keseimbangan statis dan activity of daily living pada penderita plantar faciitis. Hal itu ditunjukan dengan nilai $p<0,001$. 
Kata Kunci : Plantar Facitis, Medial Arch Support, Derajat Nyeri, Keseimbangan Statis, Activity Of Daily Living.

\section{PENDAHULUAN}

Tuntutan zaman yang semakin meningkat menyebabkan kebutuhan manusia untuk bermobilisasi semakin cepat. Kemampuan bermobilisasi ditopang dengan fisik yang sehat dan kuat. Salah satu ekstremitas yang berperan penting dalam bermobilisasi adalah kaki. Untuk melindungi bagian tubuh yang penting ini maka manusia menggunakan berbagai macam sepatu. Akan tetapi, perlindungan yang diberikan oleh sepatu adakalanya dapat membawa efek yang merugikan yaitu timbulnya nyeri. Gejala nyeri tersebut terutamanya sering disebabkan oleh plantar fascitis yaitu suatu peradangan pada plantar fascia (telapak kaki) atau dapat disebabkan karena saraf terjepit. Pada keadaan kronis dapat mengakibatkan gangguan pada kaki, lutut, pinggul dan punggung (Rica, 2013).

Fasciitis plantaris sering terjadi pada usia 40-70 tahun, tetapi pada seseorang yang mempunyai kelainan bentuk kaki (abnormal foot) yaitu telapak kaki datar (flat foot) bisa terjadi pada usia kurang dari 40 tahun. Fasciitis plantaris dapat disebabkan oleh banyak faktor, antara lain obesitas, degenerasi, overuse, flat foot dan pes cavus, pelari/olahragawan dan tightness otot gastrocnemius atau soleus.

Penanganan nyeri pada plantar faciitis banyak dilakukan seperti minum obat pengurang rasa sakit, suntikan corticosteroid, penggunaan sepatu yang nyaman (ortotik), penggunaan heel pads (ortotik), dan fisioterapi.

Pada kasus plantar faciitis Ortotik Prostetik sangat berperan penting dalam meningkatkan derajat kesehatan pada masyarakat, dimana kesehatan merupakan suatu hal yang penting bagi masyarakat. Pada penanganan plantar faciitis, ortotik prostetik dapat memberikan pelayanan ortosis berupa medial arch support dengan bahan spon dan plastik, yang bertujuan untuk memberikan support pada daerah plantaris kaki, sehingga bisa mengurangi rasa nyeri dan meningkatkan keseimbangan statis.

\section{METODE PENELITIAN \\ Subjek Penelitian}

Subjek dalam penelitian ini adalah 30 orang penderita plantar facitis yang dibagi menjadi dua kelompok.

\section{Teknik Pengumpulan data}

Data yang digunakan dalam penelitian ini adalah data primer. Teknik pengumpulan data menggunakan studi dokumentasi dan observasi.

\section{Ananlisis Data}

Pengaruh antara variabel pengaruh metode Medial Arch Support dan Ultrasound terhadap penurunan derajat nyeri, keseimbangan statis dan Activity Daily Living, dianalisis menggunakan suatu model analisis multivariate, yaitu analisis regresi linear ganda. Model analisis regresi linier ganda sebagai berikut:

$\mathrm{Y}=\mathrm{a}+\mathrm{b}_{1} \mathrm{X}_{1}+\mathrm{b}_{2} \mathrm{X}_{2}$

$\mathrm{Y}=$ Postest (Nyeri, Keseimbangan Statis dan Activity Daily Living)

$\mathrm{X}_{1}=$ Pretest MAS (Nyeri, Keseimbangan Statis dan Activity Daily Living)

$\mathrm{X}_{1}=$ Pretest US (Nyeri, Keseimbangan Statis dan Activity Daily Living)

Pengaruh dari penggunaan metode Medial Arch Support dan Ultrasound terhadap penurunan nyeri, keseimbangan 
statis dan Activity Daily Living ditunjukkan oleh koefisien regresi $b$. Kemaknaan statistik dari variable diuji dengan uji t dengan hasil ditunjukkan oleh nilai $p$ value.

\section{HASIL PENELITIAN}

Berdasarkan analisis data yang dilakukan dengan menggunakan teknik analisis regresi linier berganda pada program SPSS versi 18.0, diketahui bahwa. Hasil uji statistik dengan mann whitney menunjukkan diperoleh nilai $(p=$ 0,000) sehingga ada perbedaan penggunaan medial arch support dan ultrasound (US) terhadap pengurangan derajat nyeri pada pasien plantar fasciitis (postest).

\section{PEMBAHASAN}

Hasil uji statistik dengan independent sample t-test menunjukkan diperoleh nilai $(p=0,000)$ sehingga ada perbedaan penggunaan medial arch support dan ultrasound terhadap keseimbangan statis pada pasien plantar fasciitis (postest).

Hasil uji statistik dengan mann whitney menunjukkan diperoleh nilai $(p=$ 0,000) sehingga ada perbedaan penggunaan medial arch support dan ultrasound terhadap activity daily living pada pasien plantar fasciitis (postest).

\section{KESIMPULAN DAN SARAN Kesimpulan}

Ada pengaruh Medial Arch Support terhadap penurunan derajat nyeri pada penderita plantar fasciitis. Derajat nyeri menggunakan Medial Arch Support lebih rendah dari pada ultrasound ( $p<$ 0,001)

Ada pengaruh Medial Arch Support terhadap keseimbangan statis pada penderita plantar fasciitis. Keseimbangan statis menggunakan Medial Arch Support lebih tinggi dari pada ultrasound ( $p<0,001)$

Ada pengaruh Medial Arch Support terhadap activity daily living pada penderita plantar fasciitis. Activity daily living menggunakan Medial Arch Support lebih tinggi dari pada ultrasound ( $p<$ 0,001 )

\section{Saran}

Beberapa saran yang dapat dikemukakan dari hasil penelitian ini adalah sebagai berikut :

1. Bagi masyarakat.

Bagi penderita plantar faciitis dan orang di sekitarnya perlunya meningkatan pemahaman tentang upaya penanganan kondisi kaki plantar faciitis yang baik dan benar dalam pandangan medis sehingga dapat mencegah kecacatan lebih lanjut dengan konsultasi kepada ahli fisioterapis.

2. Bagi Institusi Pendidikan

Institusi pendidikan hendaknya berperan untuk memberikan edukasi dan meningkatkan pengetahuan masyarakat tentang peran dan manfaat ortotik prostetik perlu terus ditingkatkan melalui pemberian konsultasi ataupun mengadakan seminar kesehatan.

3. Bagi Praktisi Ortotis Prostetiis

Praktisi hendaknya terus mengadakan inovasi dengan melakukan penelitian tentang manfaat, kelebihan dan kekurangan dari bahan-bahan yang dipilih untuk mengembangkan pengetahuan ortotik prostetik dan pelayanan ortotik prostetik di masyarakat.

4. Bagi Peneliti Selanjutnya

Peneliti selanjutnya hendaknya melakukan penelitian lain di bidang fisioterapi ataupun dengan metode yang lain dalam penanganan plantar fasciitis. 


\section{DAFTAR RUJUKAN}

Katz, S., Down, T.D., Cash, H.R., \& Grotz, R.C. 1970. Progress in the development of the index of ADL. The Gerontologist, 10 (1), 20-30

Kozier, E; Berman dan Snyder. 2010. Fundamental Keperawatan: Konsep, Proses, \& Praktek, Jakarta : EGC

Kurniawan, A. 2013. Plantar Fascilitis. diakses dari http://www.ismc.co.id, tanggal 27 Nopember 2015.

Lawson, K. 2007. Standard of Care: Plantar Fasciitis. Brighamand Women's Hospital Department of Rehabilitation Services Physical Therapy.

Maryam, R.S. 2008. Mengenal Usia Lanjut dan Perawatannya. Jakarta : Salemba Medika.

Nadiaty, AH. 2015. Pengaruh Medial Arch Support Terhadap Peningkatan Keseimbangan Statis Mahasiswa Jurusan Ortotik Prostetik POLTEKKES

KEMENKES Surakarta. Surakarta : Prostetik Poltekkes Kemenkes Surakarta

Novita, D. 2012. Pengaruh Terapi Musik Terhadap Nyeri Post Operasi Open Reduction and Interval Fixation (Orif) di RSUD DR. H. Abdul Moeloek Propinsi Lampung. Tesis. Fakultas Ilmu Perawatan Program Pascasarjana Magister Ilmu Keperawatan Kekhususan Keperawatan Medikal Bedah Universitas Indonesia. Tidak dipublikasikan.

Putz, R. and Pabst, R., 2005. Otot Bahu Tampak Depan. Atlas Anatomi Manusia Sobotta Kepala, Leher,
Extremitas Atas. Jakarta: Penerbit Buku Kedokteran EGC.

Roxas, M. 2005. Plantar fasciitis: diagnosis and therapeutic considerations. Alt Med Rev. 2005; 10:83-93.

Rustanti, M dan Wahyu, SD. 2014. Pengaruh Penggunaan Medial Arch Support Terhadap Penurunan Derajat Nyeri Pada Kasus Plantar Faciitis. Jurnal Terpadu Ilmu Kesehatan. hal 106-214

Salam, M.S.A dan ELhafz, Y.N.A. 2011. Low-Dye Taping Versus Medial Arch Support in Managing Pain and Pain-Related Disability in Patients With Plantar Fasciitis. Clinical Research : 86-91.

Siburian. 2008. Buku Ajar Ilmu Penyakit Dalam. Jakarta: Balai Penerbit FKUI

Siswiyanti; Susilowati; Pudjiastuti, SS. 2013. Pengaruh Pemberian Edukasi Dan Medial Arch Support Terhadap Keseimbangan Dinamis Pada Kondisi Fleksibel Flatt Foot Anak Usia 8 s/d 10 Tahun. Jurnal Terpadu Ilmu Kesehatan : hlm.41155

Smeltzer, S.C dan Bare, B.G. 2002. Textbook of Medical-Surgical Nursing. Philadelphia : Lippincott Williams \& Wilkins.

Suhartono. 2005. Keseimbangan Postural Pada Lansia, Tesis. Program Pascasarjana Magister Kesehatan Masyarakat, Semarang : Universitas Diponegoro, Semarang. Tidak dipublikasikan.

Syatibi, MM. 2014. Pengaruh Trunk Control Activity Terhadap Tingkat Kemandirian Aktivitas Kehidupan Sehari-Hari (Activity Of Daily Living) Pasien Pasca Stroke. 
Jurnal Terpadu Ilmu Kesehatan : $15-22$

Tamsuri, A. 2007. Konsep dan Penatalaksanaan Nyeri. Jakarta : EGC

Thing, J; Maruthappu, M; Rogers, J. 2012. Diagnosis and Management of Plantar Fasciitis in Primary Care. British Journal of General Practice : 443-444.

Tillman, M. 2006. Environmental Toxicants : Human Exposures and Their Health Effect. New Jersey : Jhon Wiley \& Son.

Wibowo, H. 2011. Pencegahan dan Penatalaksanaan Cedera Olahraga. Jakarta : EGC

Wijaya, IPA. 2014. Analisis Faktor-Faktor yang Mempengaruhi Intensitas Nyeri Pasien Pasca Bedah Abdomen Dalam Kontek Asuhan Keperawatan di RSUD Badung Bali. Jurnal Dunia Kesehatan : 4757. 